\title{
The Fitness of Mass Rearing Food on the Establishment of Chrysopa pallens in a Banker Plant System under Fluctuating Temperature Conditions
}

\author{
Jie Wang ${ }^{1,2,+}$, Shu Li ${ }^{2,+}{ }^{+}$Jun Yang ${ }^{3}$, Mingcheng Guo ${ }^{3}$, Huijie Dai ${ }^{4}$, Ricardo Ramirez-Romero ${ }^{5}$, Zhenyu Jin ${ }^{1, *}$ \\ and Su Wang $2, *(1)$
}

check for

updates

Citation: Wang, J.; Li, S.; Yang, J.; Guo, M.; Dai, H.; Ramirez-Romero, R.; Jin, Z.; Wang, S. The Fitness of Mass Rearing Food on the Establishment of Chrysopa pallens in a Banker Plant System under Fluctuating Temperature Conditions. Insects 2021, 12, 1014. https://doi.org/10.3390/ insects12111014

Academic Editor: Kent M. Daane

Received: 30 September 2021 Accepted: 5 November 2021 Published: 11 November 2021

Publisher's Note: MDPI stays neutral with regard to jurisdictional claims in published maps and institutional affiliations.

Copyright: (c) 2021 by the authors. Licensee MDPI, Basel, Switzerland. This article is an open access article distributed under the terms and conditions of the Creative Commons Attribution (CC BY) license (https:// creativecommons.org/licenses/by/ $4.0 /)$.
1 Institute of Entomology, College of Agriculture, Yangtze University, Jingzhou 434020, China; wi_insect@126.com

2 Institute of Plant \& Environment Protection, Beijing Academy of Agriculture and Forestry Sciences, Beijing 100097, China; lishu@ipepbaafs.cn

3 Institute for the Control of Agrochemicals, Ministry of Agriculture and Rural Affairs, Beijing 100125, China; yangjun2008@agri.gov.cn (J.Y.); guomc90@163.com (M.G.)

4 College of Agriculture and Environment, Weifang University of Science \& Technology, Shouguang 262700, China; climsion@126.com

5 Biological Control Laboratory, Department of Agricultural Production, CUCBA, University of Guadalajara, Zapopan 317300, Mexico; rramirez@cucba.udg.mx

* Correspondence: ahk_731@163.com (Z.J.); wangsu@ipepbaafs.cn (S.W.)

+ These authors contributed equally to this work.

Simple Summary: The predatory lacewing, Chrysopa pallens, a generalist predator in the field, plays an important role in sustainable, integrated pest management strategies by allowing a reduction in the use of chemical pesticides. However, the effect of mass rearing food, i.e., eggs of the rice moth Corcyra cephalonica, on the establishment of $C$. pallens in a banker plant system in the field is unknown. Based on the age-stage, two-sex life table, and predation rate data of $C$. pallens ever cultured on the C. cephalonica eggs or the aphid Megoura japonica preying on Aphis craccivora under fluctuating temperature conditions in a greenhouse, we found that $C$. pallens could complete their development fed on A. craccivora regardless of the food used during culture. This suggests that rice moth eggs could be provided for the mass rearing of predatory lacewings without affecting their population development and biological performance in practical applications compared with lacewings cultured on aphids. This information can serve as a basis for the application of a banker plant system with the mass reared C. pallens in the field.

Abstract: Banker plant systems can be used to sustain a reproducing population of biological control agents (BCAs) within a crop, thus providing long-term pest suppression. The founder population of natural enemies in banker plant systems is usually mass-reared on factitious hosts. Thus, a better understanding of the population fitness and pest control performance of mass-reared BCAs in the field is crucial when developing integrated pest management (IPM) strategies. In this study, we determined the fitness of the generalist predator, Chrysopa pallens (Hemiptera: Chrysopidae) ever cultured on different food sources (i.e., mass rearing food, Corcyra cephalonica eggs, and aphid food, Megoura japonica) preying on Aphis craccivora in a banker plant system in a greenhouse based on Chi's age-stage, two-sex life table analysis method. The life tables and predation rate parameters of C. pallens were not significantly different between both treatments under fluctuating temperature conditions. Corcyra cephalonica eggs did not significantly weaken the performances of C. pallens in a Vicia faba-A. craccivora banker plant system compared to aphids. In conclusion, C. cephalonica eggs can be used for the mass production of $C$. pallens as the founder population in a banker plant system. Moreover, linking the life table data with the predation rate is an effective strategy for evaluating mass rearing programs in establishing banker plant systems.

Keywords: banker plant; Corcyra cephalonica; lacewing; greenhouse; life table; predation; biological control 


\section{Introduction}

Biological control agents (BCAs), including parasitoids and predators, play an important role in integrated pest management (IPM) strategies that can lead to a reduction in the use of chemical pesticides [1-4]. Both biocontrol theory and practice suggest that generalist predators can be effective BCAs in IPM [5-7]. As a generalist predator, the green lacewing, Chrysopa pallens (Rambur) (Hemiptera: Chrysopidae) has been valued for the biological control of pests in agriculture and forestry [8]. It is carnivorous during both the adult and larval stages $[9,10]$ and preys on various pests, including aphids [11], whiteflies, mites [12], and lepidopteran larvae [13]. Research on C. pallens has mainly focused on its biology [14,15], investigating the effect of an artificial diet [16-18], diapause [14,19], and the detrimental effects of transgenic crops [20,21]. However, knowledge regarding the practical application of $C$. pallens in the field is still far from complete. In particular, the successful establishment of BCA populations released into agroecosystems is challenging and may be heavily reliant on various means to support their populations [22]. Therefore, the development of strategies to support BCA populations could be useful in extending the adoption and efficacy of BCAs in practical applications.

Banker plant systems can be used to sustain a population of reproducing BCAs within a crop, thereby providing long-term pest suppression [23]. By providing shelter and alternative prey/hosts, banker plants can enable the early colonization of these natural enemies [24] and the establishment of their populations when target pests are scarce [25]. Moreover, maintaining the populations of BCAs within an agroecosystem can limit secondary outbreaks of pest populations [26]. Banker plant systems (Vicia faba-Aphis craccivora-C. pallens) that support C. pallens have been developed for pest biological control in commercial greenhouses ( $\mathrm{Li} \mathrm{S}$, unpublished data), whereas the founder population of natural enemies in banker plant systems is usually mass-reared on factitious hosts $[27,28]$. Thus, a better understanding of the population fitness and pest control performance of mass-reared BCAs is crucial for developing IPM strategies [1,29].

With the mass application of $\mathrm{BCAs}$, there has been increasing interest in the mass rearing of BCAs on factitious hosts [1,2,4]. Hemipteran herbivores (e.g., Megoura japonica) [29], dipteran larvae (e.g., Ceratitis capitata) [30], lepidopteran eggs (e.g., Ephestia kuehniella, Sitotroga cerealella) or larvae (Musca domestica) [31-34], and artificial diets [35,36] are valued as factitious hosts of BCAs. Among them, Corcyra cephalonica eggs, a traditional factitious host for mass rearing BCAs, have been well developed for the mass production of parasitoids (e.g., Trichogramma wasps) [4] and predators (e.g., Orius sauteri [37], Delphastus catalinae [38], and predatory lacewings [39,40]). Studies have revealed the suitability of food for the multigenerational mass rearing of BCAs (e.g., parasitoid wasps and predatory mites) [41-43]. Nonetheless, only scarce information is available on the adaption of C. pallens for mass production in a banker plant system.

The age-stage, two-sex life table, composed of comprehensive datasets regarding the survival, development, and fecundity of a population [44], can precisely delineate stage differentiation, including both sexes in data analysis, description, and interpretation as well as in practical applications [45]. Many studies have used this method to evaluate the effect of temperature, host plant or prey, pesticide, etc. on insects [45-48]. It is a promising research tool that can accurately assess the field population size and compare the effects of different food sources and environmental conditions on BCAs in pest management. Moreover, linking the life table with the predation rate is also an effective strategy for successful mass rearing programs and the field application of BCAs $[45,49,50]$.

Furthermore, assessing the field population size and stage structure of BCAs is an important topic in pest management and the conservation of beneficial species [45]. In order to facilitate BCAs for biological control, it is valuable to identify the features of populations that are affected by variations in field conditions. Studies have revealed that life history traits are generally affected by fluctuations in the field [51-53]. Improving our knowledge of the population characteristics of BCAs in field conditions will be helpful in the mass rearing of insects and their application as natural predators of pests [44]. 
Therefore, to attain a comprehensive understanding of the fitness of mass rearing food on the establishment of $C$. pallens in a banker plant system, we collected data on the population dynamics and predation rate of $C$. pallens cultured on different food sources (i.e., food for mass rearing or "egg food", C. cephalonica eggs, and "aphid food", M. japonica aphids) in a $V$. faba-A. craccivora banker plant system under fluctuating temperature conditions. We then analyzed the raw data using the age-stage, two-sex life table. Lastly, we discussed the effects of fluctuating conditions on the development and predation rates of BCAs.

\section{Materials and Methods}

\subsection{Insects}

Twenty pairs of adults were collected from Beijing Noah Agricultural Development Co., Ltd. (116 $59^{\prime}$ E, $\left.40^{\circ} 6^{\prime} \mathrm{N}\right)$, Beijing, China, in April 2015. For the establishment of the experimental populations for different food treatments, colonies of $C$. pallens were reared on "aphid food" with M. japonica and "egg food" with C. cephalonica eggs for 10 generations in different custom-made culturing cages $(60.0 \mathrm{~cm}$ width $\times 60.0 \mathrm{~cm}$ length $\times 60.0 \mathrm{~cm}$ height, constructed using aluminum frames and a plastic fabric 80 mesh net as the walls). In the aphid food treatment, we reared the lacewings with the M. japonica food source on broad bean ( $V$. faba) with 3-7 true leaves following the method of Cheng et al. [54]. In the egg food treatment, the lacewings were reared following the method of Zhang et al. [55]. The C. cephalonica culture was reared at $22-28{ }^{\circ} \mathrm{C}$ and $70 \pm 5 \% \mathrm{RH}$. Fresh eggs were collected daily from rearing plates and exposed to irradiation from an ultraviolet lamp for at least $24 \mathrm{~h}$ to kill the embryo. Chrysopa pallens were reared with 150 eggs per adult per day, and black papers were provided for oviposition. Either 50 or 100 eggs were provided daily for first- and second- or third-instar larvae, respectively.

Aphis craccivora was reared on broad bean. The insects and plants were monitored daily. If necessary, plants were replaced in case of damage caused by aphids. All cultures of C. pallens and aphids were kept in air-conditioned rooms at $25 \pm 1{ }^{\circ} \mathrm{C}$ and $50-70 \% \mathrm{RH}$, with a 16:8 h (L:D) photoperiod at the Institute of Plant and Environment Protection, BAAFS, Beijing, China.

\subsection{Evaluation of Population Colonization of Chrysopa pallens Using Life Tables and Predation Rates}

Experiments were conducted in a commercial greenhouse $\left(450 \mathrm{~m}^{2}\right)$ from mid-July to late August 2016 (temperature: $26.2{ }^{\circ} \mathrm{C}$ average, range $20.6-38.2{ }^{\circ} \mathrm{C}$; relative humidity: range 53-94\%) at Beijing Noah Agricultural Development Co., Ltd., (116 59' E, 40 $6^{\prime}$ N), Beijing, China. A total of 100 eggs of C. pallens were collected within $24 \mathrm{~h}$ from lacewings cultured in each of the two food treatments. The hatched larvae were transferred to individual glass tubes ( $2 \mathrm{~cm}$ in diameter, $7 \mathrm{~cm}$ in height) covered with an 80-mesh cotton net within $24 \mathrm{~h}$. Fifty or 100 third- or fourth-instar A. craccivora were provided daily to firstand second- or third-instar larvae, respectively, until cocooning. All tubes were placed on a shelf in the greenhouse. Fresh aphids (maintained on broad bean leaf) were supplied daily. The development and survival of each remaining larva and aphid were recorded daily. After the adults emerged, male and female individuals were paired in a cylindrical glass container ( $8 \mathrm{~cm}$ in diameter, $5 \mathrm{~cm}$ in height) covered with an 80-mesh cotton net and fed 200 aphids daily. Each day, the survivorship and predation rate of $C$. pallens were recorded, with $A$. craccivora being replaced. When the female adult began to oviposit (about 7 days after eclosion), the female and male adults were separated and placed in individual glass cylindrical containers as mentioned above. A total of 100 aphids were provided daily. The survival, number of eggs laid, and the adult longevity were monitored and recorded daily at regular intervals until the death of the female adult. The longevity, fecundity, and predation rate were recorded daily. The mean daily predation rate per adult was averaged for both sexes because adults were kept as pairs before oviposition. 


\subsection{Life Table Analysis}

The development period, survivorship, longevity of individuals, and female daily fecundity of $C$. pallens were analyzed using an age-stage, two-sex life table in the TWOSEXMSChart program [56-58]. The age-stage-specific fecundity $\left(f_{x j}\right.$, where $x=$ age and $j=$ stage), age-specific survival rate $\left(l_{x}\right)$, age-specific fecundity curve $\left(m_{x}\right)$, preoviposition period of female adults (APOP), total preoviposition period of females from birth (TPOP), and key population parameters $(r$, the intrinsic rate of increase; $k$, the finite rate of increase; $R_{0}$, the net reproductive rate; $T$, the mean generation time) were calculated accordingly.

The age-specific survival rate $\left(l_{x}\right)$ and age-specific fecundity $\left(m_{x}\right)$ were calculated as described by Chi and Liu [56] as follows:

$$
\begin{gathered}
l_{x}=\sum_{j=1}^{\beta} s_{x j} \\
m_{x}=\frac{\sum_{j=1}^{\beta} s_{x j} f_{x j}}{\sum_{j=1}^{\beta} s_{x j}} .
\end{gathered}
$$

The intrinsic rate of increase $(r)$ was calculated using the following formula [59]:

$$
\sum_{x=0}^{\infty} e^{-r(x+1)} l_{x} m_{x}=1 .
$$

The net reproductive rate $\left(R_{0}\right)$ was calculated as

$$
R_{0}=\sum_{x=0}^{\infty} l_{x} m_{x} .
$$

The mean generation time $(T)$ was calculated as $T=\ln R_{0} / r$.

The finite rate of increase $(\lambda)$ was calculated as $\lambda=e^{r}$.

The gross reproduction rate (GRR) was calculated using the following formula [60]:

$$
G R R=\sum m_{x} .
$$

\subsection{Predation Rate Analysis}

The CONSUME-MSChart computer program [61] was used to analyze the predation rates. Following Chi and Yang [57], the age-specific predation rate $\left(k_{x}\right)$ was calculated as:

$$
k_{x}=\frac{\sum_{j=1}^{\beta} S_{x j} C_{x j}}{\sum_{j=1}^{\beta} S_{x j}} .
$$

The age-specific net predation rate $\left(q_{x}\right)$ was calculated as

$$
q_{x}=l_{x} k_{x} .
$$

The cumulative predation rate $\left(C_{y}\right)$ was calculated as

$$
C_{y}=\sum_{x=0}^{y} l_{x} k_{x} .
$$

The net predation $\left(C_{0}\right)$ was calculated as

$$
C_{0}=\sum_{x=0}^{\infty} l_{x} k_{x} .
$$


The transformation rate from prey population to predator offspring $\left(Q_{p}\right)$ was calculated as $Q_{p}=C_{0} / R_{0}$.

To compare the predation capacity of a predator on various prey, Yu et al. [30] defined the finite predation rate $(\omega)$ as $\omega=\lambda \psi$, where $\lambda$ is the finite rate of the predator population and $\psi$ is the stable predation rate.

\subsection{Statistical Analysis}

The bootstrap method was used to estimate the standard errors of the developmental time, fecundity, longevity, and population parameters [62] using 100,000 bootstraps in the TWOSEX-MSChart program [58]. The variances and standard errors of $C_{0}, Q_{p}, \omega$, and $\lambda$ were estimated using the same 100,000 bootstrap samples from the life table analysis. The bootstrap subroutine is included in the CONSUME-MSChart program [61]. The significance of differences between treatments were calculated using the paired bootstrap test based on the 95\% confidence interval in the TWOSEX-MSChart [58] and CONSUME-MSChart programs [61].

\section{Results}

\subsection{Age-Stage, Two-Sex Life Table of Chrysopa pallens}

The developmental time and adult longevity of $C$. pallens were not significantly different between $C$. cephalonica eggs and $M$. japonica treatments under fluctuating temperature conditions in the greenhouse (Table 1). The egg, first-, second-, and third-instar larva, and pupa durations of $C$. pallens were cultured on aphid food (M. japonica) was 3.1, 2.7, 3.0, 4.3, and 13.0 days, respectively. When cultured on rice moth eggs, the female C. pallens had increased longevity (17.7 days) and males had decreased longevity (7.7 days) compared to those cultured on aphid food. Moreover, no significant differences were found in the APOP, TPOP, and fecundity between both treatments (Table 1).

Table 1. Developmental time, longevity, and fecundity of Chrysopa pallens ever cultured on Megoura japonica and Corcyra cephalonica eggs fed on Aphis craccivora, under fluctuating temperature conditions in a greenhouse (paired bootstrap test, $\mathrm{B}=100,000$, the same lowercase letters in the same column indicate the values are not significantly different, $P>0.05$ ).

\begin{tabular}{|c|c|c|c|c|c|c|}
\hline \multirow{2}{*}{ Parameters } & \multirow{2}{*}{ Stage } & \multicolumn{2}{|c|}{ M. japonica } & \multicolumn{2}{|c|}{ C. cephalonica Eggs } & \multirow{2}{*}{$P$} \\
\hline & & $n$ & Mean \pm SE & $n$ & Mean \pm SE & \\
\hline \multirow{5}{*}{ Developmental time (days) } & Egg & 100 & $3.1 \pm 0.1 \mathrm{a}$ & 100 & $3.1 \pm 0.1 \mathrm{a}$ & 0.623 \\
\hline & 1st instar & 54 & $2.7 \pm 0.1 \mathrm{a}$ & 51 & $2.8 \pm 0.1 \mathrm{a}$ & 0.080 \\
\hline & 2nd instar & 45 & $3.0 \pm 0.2 \mathrm{a}$ & 42 & $3.1 \pm 0.1 \mathrm{a}$ & 0.644 \\
\hline & 3rd instar & 38 & $4.3 \pm 0.2 \mathrm{a}$ & 34 & $4.2 \pm 0.1 \mathrm{a}$ & 0.511 \\
\hline & Pupa & 30 & $13.0 \pm 0.2 \mathrm{a}$ & 28 & $13.1 \pm 0.2 \mathrm{a}$ & 0.620 \\
\hline \multirow{2}{*}{ Adult longevity (days) } & Female & 16 & $15.8 \pm 4.4 \mathrm{a}$ & 15 & $17.7 \pm 3.7 \mathrm{a}$ & 0.739 \\
\hline & Male & 14 & $8.5 \pm 2.7 \mathrm{a}$ & 14 & $7.7 \pm 2.3 \mathrm{a}$ & 0.820 \\
\hline APOP of female (days) & Female & 7 & $6.6 \pm 0.9 \mathrm{a}$ & 10 & $7.3 \pm 0.3 \mathrm{a}$ & 0.433 \\
\hline TPOP of female (days) & Female & 7 & $33.3 \pm 1.0 \mathrm{a}$ & 10 & $33.7 \pm 0.4 \mathrm{a}$ & 0.710 \\
\hline Fecundity (eggs/female) & Female & 16 & $35.5 \pm 14.8 \mathrm{a}$ & 14 & $33.6 \pm 11.7 \mathrm{a}$ & 0.910 \\
\hline
\end{tabular}

The age-stage specific survival rates $\left(S_{x j}\right)$ of $C$. pallens showed the probability of a newborn surviving to age $x$ and stage $j$. We can detect stage overlaps in the survival curves because $S_{x j}$ takes into account the variation in individual developmental rates among individuals (Figure 1). The results show that, under fluctuating temperature conditions in a summer greenhouse, the survival rate of $C$. pallens decreased with the developmental stage (Figure 1$)$. The age-stage-specific fecundity $\left(f_{x j}\right)$ and age-specific fecundity curve $\left(m_{x}\right)$ initially increased and then decreased with time, showing roughly periodic peaks in reproduction. The maximal daily mean fecundity of $C$. pallens cultured on $C$. cephalonica eggs (4.3 eggs) and M. japonica (4.5 eggs) was observed at 42 days (Figure 2). 

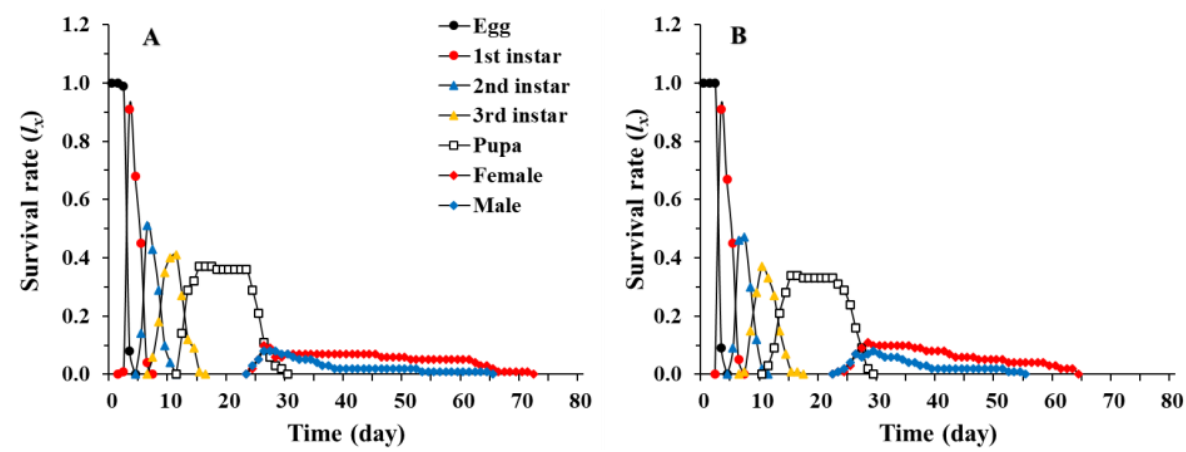

Figure 1. Age-stage specific survival rate $\left(S_{x j}\right)$ of Chrysopa pallens ever cultured on Megoura japonica (A) and Corcyra cephalonica eggs (B) under fluctuating temperature conditions in a greenhouse.
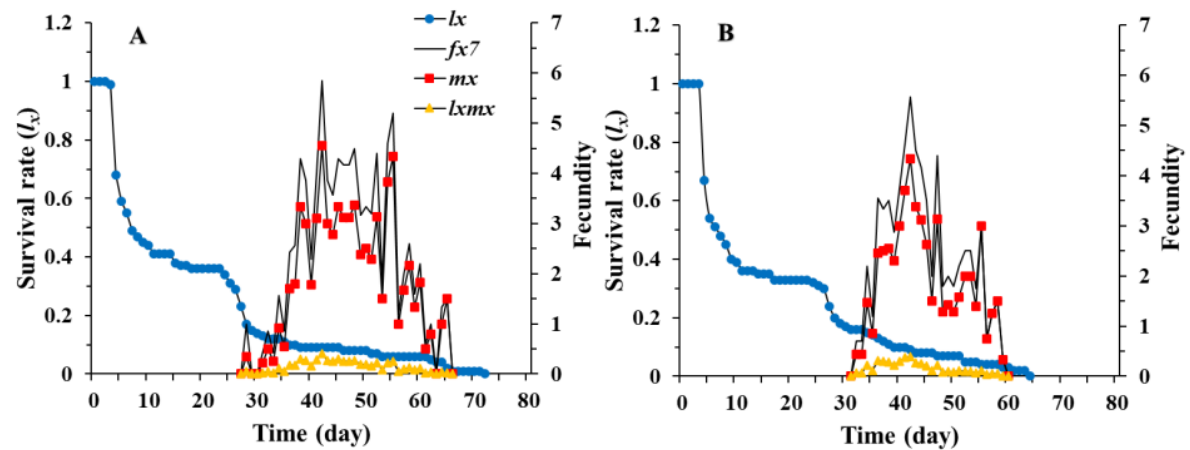

Figure 2. Age-specific survival rate $(l x)$, age-stage specific fecundity $\left(f_{x 7}\right)$ of the female stage, agespecific fecundity $(m x)$ of Chrysopa pallens ever cultured on Megoura japonica (A) and Corcyra cephalonica eggs (B) under fluctuating temperature conditions in a greenhouse.

\subsection{Population Parameters of Chrysopa pallens under Fluctuating Temperature Conditions in} a Greenhouse

The mean and standard errors of the population parameters were estimated using the bootstrap techniques [63]. When exposed to the same prey (A. craccivora) and environmental conditions, there were no significant differences in the main population parameters between both treatments. The intrinsic rates of increase $(r)$ of $C$. pallens cultured on M. japonica and C. cephalonica eggs were 0.0379 and 0.0359 , respectively (Table 2 ).

Table 2. Population parameters of Chrysopa pallens ever cultured on Megoura japonica and Corcyra cephalonica eggs fed on Aphis craccivora under fluctuating temperature conditions in a greenhouse (paired bootstrap test, B = 100,000, the same lowercase letters in the same column indicate the values are not significantly different, $P>0.05$ ).

\begin{tabular}{cccc}
\hline Population Parameter & M. japonica & C. cephalonica Eggs & $\boldsymbol{P}$ \\
\hline Intrinsic rate of increase $(\mathrm{r})\left(\right.$ day $\left.^{-1}\right)$ & $0.0379 \pm 0.0119 \mathrm{a}$ & $0.0359 \pm 0.0109 \mathrm{a}$ & 0.916 \\
Finite rate of increase $(\lambda)\left(\right.$ day $\left.^{-1}\right)$ & $1.0386 \pm 0.0122 \mathrm{a}$ & $1.0366 \pm 0.0112 \mathrm{a}$ & 0.916 \\
Net reproduction rate $\left(R_{0}\right)($ offspring individual & -1 \\
Mean generation time $(\mathrm{T})($ day) & $5.68 \pm 2.64 \mathrm{a}$ & $4.67 \pm 1.96 \mathrm{a}$ & 0.753 \\
Gross reproduction rate $(\mathrm{GRR})$ (offspring) & $45.83 \pm 1.72 \mathrm{a}$ & $42.90 \pm 1.14 \mathrm{a}$ & 0.071 \\
\hline
\end{tabular}

\subsection{Predation Rate of Chrysopa pallens under Fluctuating Temperature Conditions in a Greenhouse}

Under fluctuating temperature conditions in the greenhouse, the predation rate of larva on $A$. craccivora increased with the developmental stage. No significant differences in predation rate were found between both treatments at different developmental stages. The third-instar larvae consumed the greatest amount of prey in the larval stage, reaching 190.8 to 191.1 aphids consumed per larva. Female C. pallens lived longer and consumed more 
aphids than males regardless of the food source (Table 3). A male adult could consume as many as 270 aphids, while a female adult could consume 609 aphids in the C. cephalonica egg treatment under fluctuating temperature conditions in the greenhouse.

Table 3. Predation rates and parameters of Chrysopa pallens ever cultured on Megoura japonica and Corcyra cephalonica eggs fed on Aphis craccivora under fluctuating temperature conditions in a greenhouse (paired bootstrap test, $B=100,000$, the same lowercase letters in the same column indicate the values are not significantly different, $P>0.05$ ).

\begin{tabular}{ccccc}
\hline \multirow{2}{*}{ Parameter } & \multirow{2}{*}{ Stage } & M. japonica & C. cephalonica Eggs & \multirow{2}{*}{$\boldsymbol{P}$} \\
\cline { 3 - 4 } & & Mean \pm SE & Mean \pm SE & \\
\hline & 1st instar & $14.9 \pm 0.9 \mathrm{a}$ & $15.1 \pm 0.7 \mathrm{a}$ & 0.837 \\
Predation & 2nd instar & $35.5 \pm 2.4 \mathrm{a}$ & $35.5 \pm 2.2 \mathrm{a}$ & 0.987 \\
rate(aphids/predator) & 3rd instar & $191.1 \pm 5.7 \mathrm{a}$ & $190.8 \pm 6.3 \mathrm{a}$ & 0.954 \\
& Female & $539.0 \pm 150.0 \mathrm{a}$ & $609.0 \pm 120.0 \mathrm{a}$ & 0.715 \\
Net predation rate $C_{0}$ & Male & $291.1 \pm 79.8 \mathrm{a}$ & $270.2 \pm 68.1 \mathrm{a}$ & 0.836 \\
Transformation rate $Q_{p}$ & & $236.00 \pm 39.66 \mathrm{a}$ & $220.97 \pm 36.33 \mathrm{a}$ & 0.776 \\
Stable predation rate $\psi$ & & $54.22 \pm 43.93 \mathrm{a}$ & $55.97 \pm 29.41 \mathrm{a}$ & 0.945 \\
Finite predation rate $\omega$ & & $9.19 \pm 0.73 \mathrm{a}$ & $8.92 \pm 0.78 \mathrm{a}$ & 0.799 \\
\hline
\end{tabular}

The daily predation rate of larvae showed the same trend as the age-stage specific predation rate $\left(c_{x j}\right)$ of $C$. pallens fed on $A$. craccivora, i.e., an initial increase followed by a decrease. The daily predation rate of $C$. pallens cultured on rice moth eggs peaked for the third-instar larvae on the 13th day (55.3 aphids) and was slightly higher than when cultured on aphids (on the 12th day with 53.4 aphids). The nonpredatory stages, including eggs and pupae, were responsible for the two gaps in predation rate (Figure 3 ). Considering the sex differentiation and stage differentiation, the age-specific predation rate $\left(k_{x}\right)$ is the mean number of aphids consumed per C. pallens of age $x$. Taking the age-specific survival rate $\left(l_{x}\right)$ into account, the age-specific net predation rate $\left(q_{x}\right)$ of $C$. pallens can be obtained. With an increase in age, there is a gradual decrease in the age-specific survival rate $\left(l_{x}\right)$, and less fluctuation in the age-specific predation rate $\left(k_{x}\right)$. The age-specific predation rate $\left(k_{x}\right)$ and the age-specific net predation rate $\left(q_{x}\right)$ curve also exhibited two gaps, representing the sanctuary stage of $A$. craccivora (Figure 4 ).
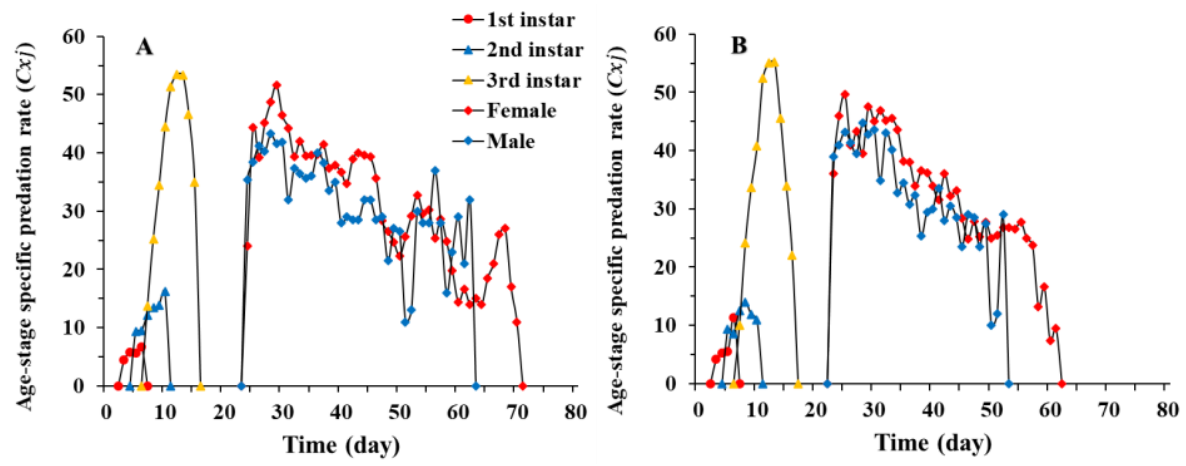

Figure 3. Age-stage specific predation rate $\left(c_{x j}\right)$ of Chrysopa pallens ever cultured on Megoura japonica (A) and Corcyra cephalonica eggs (B) under fluctuating temperature conditions in a greenhouse. 

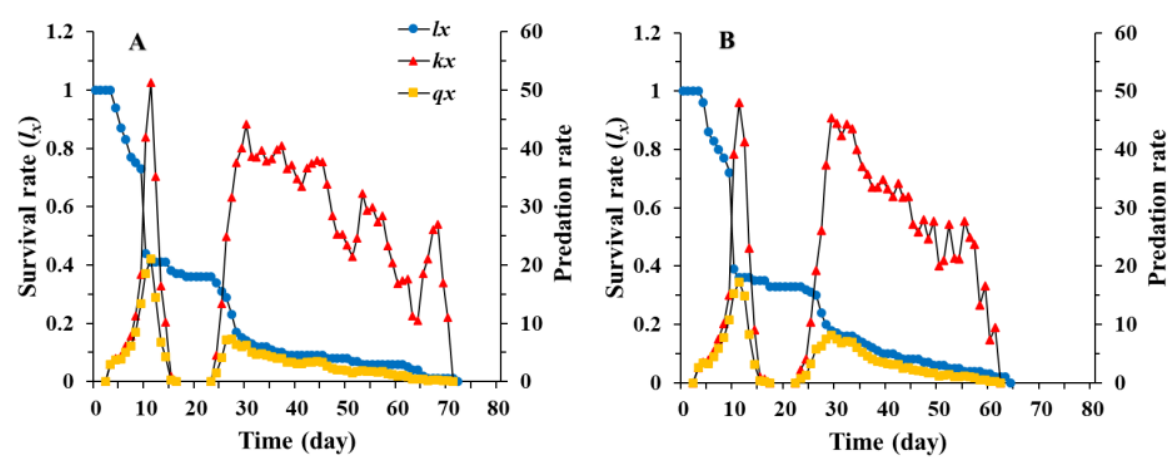

Figure 4. Age-specific survival rate $\left(l_{x}\right)$, age-specific predation rate $\left(k_{x}\right)$, and age-specific net predation rate $\left(q_{x}\right)$ of Chrysopa pallens ever cultured on Megoura japonica (A) and Corcyra cephalonica eggs (B) under fluctuating temperature conditions in a greenhouse.

The mean and standard errors of the predation rate parameters estimated by means of the bootstrap technique [63] are listed in Table 3. There were no significant differences in the main predation rate parameters between both treatments after incorporating the survival rates and predation rates. The net predation rate $\left(C_{0}\right)$ of $C$. pallens cultured on aphid food (M. japonica) was higher than when cultured on rice moth $C$. cephalonica eggs. The transformation rates $\left(Q_{p}\right)$ of $C$. pallens cultured on aphid food (M. japonica) and rice moth C. cephalonica eggs were 54.22 and 55.97, respectively (Table 3 ).

\section{Discussion}

The use of banker plants was developed to increase the effectiveness of BCAs in pest control [24,25]. Most studies on banker plant systems have focused on assessing the suitability of a plant species as a banker plant [63-65] or the fitness of alternative prey on natural enemies $[25,66]$. Conversely, studies on the population fitness of BCAs in banker plant systems using alternative prey have received less attention. Yet, with the mass production of BCAs in biocontrol application systems, the population fitness and pest control performance of BCAs in banker plant systems are crucial when developing IPM strategies. The growth rate, stage differentiation and development, fecundity, and predation rate of predatory natural enemies in the field are key to determining their biological control efficiency [67]. The age-stage, two-sex life table is a promising research tool that can be used to accurately assess the effects of different food sources and environmental conditions on BCAs [45]. In the present study, we showed that C. pallens could complete its development while preying on $A$. craccivora in a summer greenhouse. Moreover, no significant differences were found in the population and predation rate parameters of $C$. pallens when cultured on either aphid food with M. japonica or egg food in the case of C. cephalonica eggs. The study indicated that $C$. pallens mass reared on $C$. cephalonica eggs can be suitable for population colonization in a Vicia faba-A. craccivora banker plant system in IPM.

Laboratory measurements of life parameters usually take place under controlled conditions at single constant temperatures, while field conditions are much more complex with climatic conditions fluctuating over time and space $[53,68]$. As insects are ectothermic organisms, their responses to constant and fluctuating temperature can vary widely [69-73] Under controlled conditions in a laboratory, $\mathrm{Mu}$ et al. [74] showed that the development of C. pallens larvae was 10 to 12 days. Zhao [75] determined the mean developmental times of the egg, larval, and pupal stages of $C$. pallens reared on A. craccivora at $25^{\circ} \mathrm{C}$ to be $3.38,11.01$, and 13.26 days, respectively, whereas the average durations of the egg, larval, and pupal stages of $C$. pallens reared on $A$. craccivora at $22{ }^{\circ} \mathrm{C}$ were $4.3,11$, and 13 days, respectively [30]. Unlike the pupal period, the egg and larval stage durations in our study were shorter than those reported by $\mathrm{Yu}$ et al. [30]. Our results are in accordance with the results of previous studies showing that the development time of insects at constant temperature is longer than that under fluctuating temperature conditions [52,76]. On the other hand, the fecundity of female adults in the laboratory was 661 eggs according to 
Yu et al. [30], which is 18 times higher than that in our studies (33.6-35.5 eggs). Significant reductions in the survival and reproduction of $C$. pallens under greenhouse conditions can be observed in the curves of $S_{x j}$ (Figure 1), $f_{x j}$, and $m_{x}$ (Figure 2). Studies have revealed that the life history traits of insects are generally affected by fluctuations in the field [51-53]. For example, in the preadult stage of ladybird Cheilomenes sexmaculata, development occurs more slowly under greenhouse conditions, with lower survival and reproductive rates [51]. Our study also revealed different life table parameters for $C$. pallens under laboratory and greenhouse conditions, indicating that the survival rate of $C$. pallens was higher at intermediate temperatures than at high or low temperatures.

Variable temperatures have complex effects on insect performance $[77,78]$. Under controlled conditions in the laboratory, El-Serafi et al. [79] and Cheng et al. [54] studied the predation rates of $C$. pallens feeding on Aphelinidae (A. gossypii, Sitobion avenae, Rhopalosiphum maidis, $A$. nerii, and $M$. japonica). The average predation rates of females and males fed on A. craccivora in a summer greenhouse in our study were lower than the values determined by El-Serafi et al. [79] and Cheng et al. [54]. Previous studies indicated that fluctuating temperature conditions affect the life history traits of insects, often resulting in low survival rates, fecundity, and longevity $[51,78]$. Our study also indicated that the predation rate of $C$. pallens was higher at intermediate temperatures than at high or low temperatures. The shorter longevity of adults may have accounted for the lower predation rate under fluctuating temperature conditions.

Mass rearing of BCAs on alternative foods may reduce their performance during the rearing period or after release upon encountering the target prey in the field [80]. Researchers have demonstrated that the natal rearing experience of parasitoids may affect their behavioral and physiological characteristics [80-83]. Ghaemmaghami et al. [84] found that laboratory mass-reared colonies of T. brassicae (Hymenoptera: Trichogrammatidae) declined in quality after 15 generations. On the other hand, the long-term rearing of predatory mite Neoseiulus californicus (Acari: Phytoseiidae) on almond pollen positively affected its attributes, including in promoting high survivorship, body size, and fecundity [80]. Our results demonstrate that long-term feeding on mass rearing food, Corcyra cephalonica eggs, did not affect the performance of the predatory lacewing C. pallens in a $V$. faba-A. craccivora-C. pallens banker plant system. Accordingly, mass-reared predatory lacewings can be introduced into a banker plant system for IPM programs.

The specialization of predators on one kind of prey generally entails a tradeoff in performance on another [85]. The net predation rate, stable predation rate, and finite predation rate of $C$. pallens cultured on rice moth $C$. cephalonica eggs and fed on $A$. craccivora were lower than when cultured on aphid food (M. japonica). As C. cephalonica eggs were stationary when being consumed, $C$. pallens cultured on rice moth eggs had poor performance when exposed to moving prey, i.e., M. japonica. More studies need to be conducted to determine the differences in behavior of $C$. pallens cultured on different food. Although the biological performance and population parameters of $C$. pallens cultured on factitious hosts, i.e., C. cephalonica eggs, were slightly lower than when cultured on aphid food, there was no significantly negative effect. A life table study incorporating the age-stage predation rate is obviously capable of providing an accurate and thorough understanding of the predator-prey relationship as well as producing a comprehensive evaluation of the potential of a predator/parasitoid as a biological control agent $[44,50]$. In predator-prey interactions, the nonpredatory egg and pupal stages of the predator represent times of refuge for the prey, and the pest population can grow during these times. Thus, release of $C$. pallens in a mixture of development stages may help to overcome these gaps in a biological control program. That is, natural enemies in banker plant systems can be introduced at mixed stages for better population establishment and pest biological control efficiency. Although the predation rates of $C$. pallens on aphid food observed in our study were lower than those in controlled conditions [54,74,75,79], evidence of the control efficiency of $C$. pallens in practical applications suggests its potential application as a BCA in the field. 
Despite an increasing number of studies on biological control programs, there is a paucity of literature on the population and predation parameters of BCAs under variable environmental conditions, even though these are essential in the mass rearing and release of BCAs $[51,86]$. Moreover, such studies can provide a theoretical basis and practical knowledge for the application of $C$. pallens in greenhouses. Fluctuating temperature conditions as well as a higher humidity, photoperiod, and light intensity may be responsible for the lower survival rate, shorter longevity, and even lower reproduction of predators in the field [51,87]. We suggest that temperature is a key variable that restricts the adult longevity, fecundity, and predation rate of C. pallens in the field. The application of banker plant systems in commercial greenhouses require consideration of these fluctuating environments. However, there are many other factors (e.g., light, humidity, population density, and nutrition) affecting the population dynamics and predation ability of C. pallens. The susceptibility of insects to numerous environmental factors, natural enemies, and pesticides often varies in relation to their developmental stage $[47,88]$, and more studies regarding the population stage structure under critical conditions are necessary for ensuring effective pest management. Our study confirmed that linking the life table with the predation rate is an effective strategy to evaluate mass rearing programs and the field application of BCAs. Ultimately, these approaches could support the use of generalist predators in more environmentally friendly pest management methods, with reduced negative side-effects compared to regular pesticides in the field $[3,89]$.

Author Contributions: Conceptualization, S.L., Z.J. and S.W.; Methodology, S.L. and J.W.; Software, S.W., S.L. and J.W.; Validation, Z.J. and S.W.; Formal Analysis, S.L., J.W. and S.W.; Investigation, S.L. and J.W.; Resources, S.L. and J.W.; Data Curation, S.L. and J.W.; Writing-Original Draft Preparation, S.L., J.W., J.Y., M.G., H.D. and R.R.-R.; Writing-Review \& Editing, J.W., S.L., J.Y., M.G., H.D., R.R.-R., Z.J. and S.W.; Visualization, S.L. and J.W.; Supervision, S.L., Z.J. and S.W.; Project Administration, S.L.; Funding Acquisition, S.W. and S.L. All authors have read and agreed to the published version of the manuscript.

Funding: This study was supported by funds from the National Natural Science Foundation of China (ref. 32072479) and the Technical Innovation Program of Beijing Academy of Agriculture and Forestry Sciences (KJCX20200110, KJCX2021108).

Institutional Review Board Statement: Not applicable.

Informed Consent Statement: Not applicable.

Data Availability Statement: The data presented in this study are available in article.

Acknowledgments: We wish to thank Douglas Chester from the Institute of Zoology, Chinese Academy of Sciences for language correction and manuscript improvement.

Conflicts of Interest: The authors declare that there is no conflict of interests.

\section{References}

1. Van Lenteren, J.C. The state of commercial augmentative biological control: Plenty of natural enemies, but a frustrating lack of uptake. Biocontrol 2012, 57, 1-20. [CrossRef]

2. Yang, N.W.; Zang, L.S.; Wang, S.; Guo, J.Y.; Xu, H.X.; Zhang, F.; Wan, F.H. Biological pest management by predators and parasitoids in the greenhouse vegetables in China. Biol. Control 2014, 68, 92-102. [CrossRef]

3. Huang, N.X.; Jaworski, C.C.; Desneux, N.; Zhang, F.; Yang, P.Y.; Wang, S. Long-term and large-scale releases of Trichogramma promote pesticide decrease in maize in northeastern China. Entomol. Gen. 2020, 40, 331-335. [CrossRef]

4. Zang, L.S.; Wang, S.; Zhang, F.; Desneux, N. Biological control with Trichogramma in China: History, present status and perspectives. Annu. Rev. Entomol. 2021, 66, 463-484. [CrossRef] [PubMed]

5. Symondson, W.O.C.; Sunderland, K.D.; Greenstone, M.H. Can generalist predators be effective biocontrol agents? Annu. Rev. Entomol. 2002, 47, 561-594. [CrossRef]

6. Desneux, N.; O'Neil, R.J.; Yoo, H.J.S. Suppression of population growth of the soybean aphid, Aphis glycines Matsumura, by predators: The identification of a key predator, and the effects of prey dispersion, predator density and temperature. Environ. Entomol. 2006, 35, 1342-1349. [CrossRef]

7. Lu, Y.H.; Wu, K.M.; Jiang, Y.Y.; Guo, Y.Y.; Desneux, N. Widespread adoption of Bt cotton and insecticide decrease promotes biocontrol services. Nature 2012, 487, 362-365. [CrossRef] 
8. Yang, X.K. Discussion on the scientific name of Chrysopa pallens (Rambur) and related questions. Acta Entomol. Sin. 1998, 41, 106-107. (In Chinese)

9. Sterling, W.L.; El-Zik, K.M.; Wilson, L.T. Biological control of pest populations. In Integrated Pest Management Systems and Cotton Production; Frisbie, R.E., El-Zik, K.M., Wilson, L.T., Eds.; John Wiley, Son: New York, NJ, USA, 1989; pp. $155-189$.

10. Wang, Y.; Zhang, R.; Wang, M.; Zhang, L.; Shi, C.-M.; Li, J.; Fan, F.; Geng, S.; Liu, X.; Yang, D. The first chromosome-level genome assembly of a green lacewing Chrysopa pallens and its implication for biological control. Mol. Ecol. Resour. 2021. [CrossRef]

11. Tsukaguchi, S. Chrysopidae of Japan (Insecta, Neuroptera); Yutaka Publish: Hyogo, Japan, 1995.

12. Boo, K.S.; Chung, I.B.; Han, K.S.; Pickett, J.A.; Wadhams, L.J. Response of the lacewing Chrysopa cognata, to pheromones of its aphid prey. J. Chem. Ecol. 1998, 24, 631-643. [CrossRef]

13. Canard, M.; Volkovich, T.A. Outlines of lacewing development. In Lacewings in the Crop Environment; McEwen, P.K., New, R., Whittington, A.E., Eds.; Cambridge University Press: Cambridge, MA, USA, 2001; pp. 130-153.

14. Nakahira, K.; Arakawa, R. Effect of photoperiod on the development and diapause of the green lacewing Chrysopa pallens (Neuroptera: Chrysopidae). Entomol. Sci. 2005, 8, 133-135. [CrossRef]

15. Sarkar, S.C.; Wang, E.; Zhang, Z.; Wu, S.; Lei, Z. Laboratory and glasshouse evaluation of the green lacewing, Chrysopa pallens (Neuroptera: Chrysopidae) against the western flower thrips, Frankliniella occidentalis (Thysanoptera: Thripidae). Appl. Entomol. Zool. 2019, 54, 115-121. [CrossRef]

16. Choi, M.Y.; Lee, G.H.; Paik, C.H.; Lee, J.J. Development of artificial diets for green lacewing, Chrysopa pallens (Rambur), by addition of natural products. Korean J. Appl. Entomol. 2000, 39, 99-103.

17. Lee, K.S.; Lee, J.H. Rearing of Chrysopa pallens (Rambur) (Neuroptera: Chrysopidae) on artificial diet. Entomol. Res. 2005, 35, 183-188. [CrossRef]

18. Liu, F.; Liu, C.; Zeng, F. Effects of an artificial diet on development, reproduction and digestive physiology of Chrysopa septempunctata. Biocontrol 2013, 58, 789-795. [CrossRef]

19. Shi, A.J.; Xu, H.F.; Liu, Z.D.; Zhao, J.; Zhang, F.; Xu, Y.Y. Effect of photoperiod on induction of prepupal diapause and larval development in Chrysopa pallens (Rambur) (Neuroptera: Chrysopidae). Acta Ecol. Sin. 2008, 28, 3854-3859. (In Chinese)

20. Ali, I.; Zhang, S.; Iqbal, M.; Ejaz, S.; Cui, J.J. Trypsinized Cry1Fa and Vip3Aa have no detrimental effects on the adult green lacewing Chrysopa pallens (Neuroptera: Chrysopidae). Appl. Entomol. Zool. 2017, 52, 321-327. [CrossRef]

21. Ali, I.; Zhang, S.; Sajjad, A.; Rehman, H.M.U.; Cui, J.J. Artificial diet based investigation on the impact of purified Cry1Ac, Cry1Fa and $\mathrm{Cry} 2 \mathrm{Ab}$ on the survival and reproductive performance of adult green lacewing, Chrysopa pallens (Rambur) (Neuroptera: Chrysopidae). Phytoparasitica 2018, 46, 127-135. [CrossRef]

22. Bianchi, F.J.J.; Booij, C.J.H.; Tscharntke, T. Sustainable pest regulation in agricultural landscapes: A review on landscape composition, biodiversity and natural pest control. Proc. Biol. Sci. 2006, 273, 1715-1727. [CrossRef]

23. Parolin, P.; Bresch, C.; Poncet, C.; Desneux, N. Functional characteristics of secondary plants for increased pest management. Int. J. Pest Manag. 2012, 58, 369-377. [CrossRef]

24. Frank, S.D. Biological control of arthropod pests using banker plant systems: Past progress and future directions. Biol. Control 2010, 52, 8-16. [CrossRef]

25. Huang, N.X.; Enkegaard, A.; Osborne, L.S.; Ramakers, P.M.J.; Messelink, G.J.; Pijnakker, J.; Murphy, G. The banker plant method in biological control. Crit. Rev. Plant Sci. 2011, 30, 259-278. [CrossRef]

26. Zheng, X.S.; Lu, Y.H.; Zhu, P.Y.; Zhang, F.; Tian, J.C.; Xu, H.; Chen, G.; Nansen, C.; Lv, Z.X. Use of banker plant system for sustainable management of the most important insect pest in rice field in China. Sci. Rep. 2017, 7, 45581. [CrossRef] [PubMed]

27. Chen, X.; Jaworski, C.C.; Dai, H.; Liang, Y.Y.; Guo, X.J.; Wang, S.; Zang, L.S.; Desneux, N. Combining banker plants to achieve long-term pest control in multi-pest and multi-natural enemy cropping systems. J. Pest Sci. 2021. [CrossRef]

28. Sanchez, J.A.; López-Gallego, E.; Pérez-Marcos, M.; Perera-Fernández, L. The effect of banker plants and pre-plant release on the establishment and pest control of Macrolophus pygmaeus in tomato greenhouses. J. Pest Sci. 2021, 94, 297-307. [CrossRef]

29. Li, Y.Y.; Zhang, G.H.; Tian, C.B.; Liu, M.X.; Liu, Y.Q.; Liu, H.; Wang, J.J. Does long-term feeding on alternative prey affect the biological performance of Neoseiulus barkeri (Acari: Phytoseiidae) on the target spider mites? J. Econ. Entomol. 2017, 110, 915-923. [CrossRef]

30. Yu, L.Y.; Chen, Z.Z.; Zheng, F.Q.; Shi, A.J.; Guo, T.T.; Yeh, B.H.; Chi, H.; Xu, Y.Y. Demographic analysis, a comparison of the jackknife and bootstrap methods, and predation projection: A case study of Chrysopa pallens (Rambur) (Neuroptera: Chrysopidae). J. Econ. Entomol. 2013, 106, 1-9. [CrossRef]

31. Canale, A.; Benelli, G. Impact of mass-rearing on the host seeking behaviour and parasitism by the fruit fly parasitoid Psyttalia concolor (Szépligeti) (Hymenoptera: Braconidae). J. Pest Sci. 2012, 85, 65-74. [CrossRef]

32. Cocuzza, G.E.; Clercq, P.; Veire, M.; Cock, A.; Degheele, D.; Vacante, V. Reproduction of Orius laevigatus and Orius albidipennis on pollen and Ephestia kuehniella eggs. Entomol. Exp. Appl. 1997, 82, 101-104. [CrossRef]

33. Pitcher, S.A.; Hoffmann, M.P.; Gardner, J.; Wright, M.G.; Kuhar, T.P. Cold storage of Trichogramma ostriniae reared on Sitotroga cerealella eggs. Biocontrol 2002, 47, 525-535. [CrossRef]

34. Zanuncio, J.C.; Molina-Rugama, A.J.; Serrao, J.; Pratissoli, D. Nymphal development and reproduction of Podisus nigrispinus (Heteroptera: Pentatomidae) fed with combinations of Tenebrio molitor (Coleoptera: Tenebrionidae) pupae and Musca domestica (Diptera: Muscidae) larvae. Biocontrol Sci. Technol. 2001, 11, 331-337. [CrossRef] 
35. Khanzada, M.S.; Wang, S.; Huang, N.X.; Pang, H.; Tan, X.L.; Khanzada, S.R. Optimization of microencapsulated artificial diets for mass rearing of the predacious big eyed bug, Geocoris pallidipennis. Entomol. Gen. 2019, 39, 353-363. [CrossRef]

36. Tan, X.L.; Wang, S.; Zhang, F. Optimization an optimal artificial diet for the predatory bug Orius sauteri (Hemiptera: Anthocoridae). PLOS ONE 2013, 8, e61129.

37. Yang, L.W.; Zhang, F.; Zhao, J.; Li, S.; Wang, S. The effects of short-time food acclimation on the functional response of Orius sauteri reared to Corcyra cephalonica eggs. Acta Phytophylacica Sin. 2014, 41, 705-710.

38. Liang, W.X.; Wang, Z.H.; Huang, J. Effect of alternative feeding with artificial diets and natural prey on oviposition of Delphastus catalinae (Horn). Chin. J. Biol. Control 2014, 30, 600-605.

39. Alasady, M.A.A.; Omar, D.B.; Ibrahim, Y.B.; Ibrahim, R.B. Life table of the green lacewing Apertochrysa sp. (Neuroptera: Chrysopidae) reared on rice moth Corcyra cephalonica (Lepidoptera: Pyralidae). Int. J. Agric. Biol. 2010, 12, $266-270$.

40. Khuhro, N.H.; Chen, H.Y.; Zhang, Y.; Zhang, L.S.; Wang, M.Q. Effect of different prey species on the life history parameters of Chrysoperla sinica (Neuroptera: Chrysopidae). Eur. J. Entomol. 2012, 109, 175-180. [CrossRef]

41. Li, X.Y.; Lei, Q.; Hua, H.Q.; Song, H.F.; Wang, S.; Ramirez-Romero, R.; Dai, H.J.; Li, J.T.; Li, Y.X. Impact of host suitability on oviposition preference toward fertilized and unfertilized host eggs in two Trichogramma parasitoid species. Entomol. Gen. 2019, 39, 313-323. [CrossRef]

42. Lü, X.; Han, S.C.; Li, Z.; Li, L.Y. Biological characters of Trichogramma dendrolimi (Hymenoptera: Trichogrammatidae) reared in vitro versus in vivo for thirty generations. Sci. Rep. 2017, 7, 17928. [CrossRef]

43. Wang, Y.; Zou, Z.P.; Hou, Y.Y.; Yang, X.B.; Wang, S.; Dai, H.J.; Xu, Y.Y.; Zang, L.S. Manually-extracted unfertilized eggs of Chinese oak silkworm, Antheraea pernyi, enhance mass production of Trichogramma parasitoids. Entomol. Gen. 2020, 40, 397-406. [CrossRef]

44. Yu, J.Z.; Chi, H.; Chen, B.H. Comparison of the life tables and predation rates of Harmonia dimidiate (F.) (Coleoptera: Coccinellidae) fed on Aphis gossypii Glover (Hemiptera: Aphididae) at different temperatures. Biol. Control 2013, 64, 1-9. [CrossRef]

45. Chi, H.; You, M.S.; Atlihan, R.; Smith, C.L.; Kavousi, A.; Özgökçe, M.S.; Güncan, A.; Tuan, S.J.; Fu, J.W.; Xu, Y.Y.; et al. Age-stage, two-sex life table: An introduction to theory, data analysis, and application. Entomol. Gen. 2020, 40, 103-124. [CrossRef]

46. Wang, S.X.; Di, N.; Chen, X.; Zhang, F.; Biondi, A.; Desneux, N.; Wang, S. Life history and functional response to prey density of the flower bug Orius sauteri attacking the fungivorous sciarid fly Lycoriella pleuroti. J. Pest Sci. 2018, 92, 715-722. [CrossRef]

47. Xiao, D.; Zhao, J.; Guo, X.J.; Chen, H.Y.; Qu, M.M.; Zhai, W.G.; Desneux, N.; Biondi, A.; Zhang, F.; Wang, S. Sublethal effects of imidacloprid on the predatory seven-spot ladybird beetle Coccinella septempunctata. Ecotoxicology 2015, 25, 1782-1793. [CrossRef]

48. Zhang, Y.; Guo, L.; Atlihan, R.; Chi, H.; Chu, D. Demographic analysis of progeny fitness and timing of resurgence of Laodelphax striatellus after insecticides exposure. Entomol. Gen. 2019, 39, 221-230. [CrossRef]

49. Ding, H.Y.; Lin, Y.Y.; Tuan, S.J.; Tang, L.C.; Chi, H.; Atlıhan, R.; Özgökçe, M.S.; Güncan, A. Integrating demography, predation rate, and computer simulation for evaluation of Orius strigicollis as biological control agent against Frankliniella intonsa. Entomol. Gen. 2021, 42, 179-196. [CrossRef]

50. Tuan, S.J.; Yeh, C.C.; Atlihan, R.; Chi, H. Linking life table and predation rate for biological control: A comparative study of Eocanthecona furcellata fed on Spodoptera litura and Plutella xylostella. J. Econ. Entomol. 2016, 109, 13-24. [CrossRef]

51. Zhao, J.; Li, S.; Gao, X.W.; Zhang, F.; Wang, S. Comparison of life tables of Cheilomenes sexmaculata (Coleoptera: Coccinellidae) under laboratory and greenhouse conditions. J. Econ. Entomol. 2015, 108, 1700-1707. [CrossRef]

52. Milosavljevi 'c, I.; McCalla, K.A.; Ratkowsky, D.A.; Hoddle, M.S. Effects of constant and fluctuating temperatures on development rates and longevity of Diaphorencyrtus aligarhensis (Hymenoptera: Encyrtidae). J. Econ. Entomol. 2019, 112, 1062-1072. [CrossRef]

53. Chen, L.; Enkegaard, A.; Sørensen, J.G. Temperature affects biological control efficacy: A microcosm study of Trichogramma achaeae. Insects 2021, 12, 95. [CrossRef]

54. Cheng, L.Y.; Liao, X.J.; Xu, L.X.; Sun, L.; Chen, Z.Z.; Xu, Y.Y. Two-sex life table and predation of Chrysopa pallens (Rambur) feeding on Megoura japonica (Matsumura). Acta Phytophylacica Sin. 2014, 41, 680-686.

55. Zhang, F.; Wang, S.; Wang, B.; Guo, X.J.; Zhang, J.M.; Xiao, D. Breeding the Larvae Chrysopa Pallens with Rice Moth Eggs. Application No. CN105746435A, 13 July 2016.

56. Chi, H.; Liu, H. Two new methods for the study of insect population ecology. Bull. Inst. Zool. 1985, 24, 225-240.

57. Chi, H.; Yang, T.C. Two-sex life table and predation rate of Propylaea japonica Thunberg (Coleoptera: Coccinellidae) fed on Myzus persicae (Sulzer) (Homoptera: Aphididae). Environ. Entomol. 2003, 32, 327-333. [CrossRef]

58. Chi, H. TWOSEX-MSChart: A Computer Program for the Age-Stage, Two-Sex Life Table Analysis; National Chung Hsing University: Taichung, Taiwan. Available online: http:/ /140.120.197.173/Ecology/prod02.htm (accessed on 25 December 2019).

59. Goodman, D. Optimal life histories, optimal notation, and the value of reproductive value. Am. Nat. 1982, 119, 803-823. [CrossRef]

60. Chi, H.; Su, H.Y. Age-stage, two-sex life tables of Aphidius gifuensis (Ashmead) (Hymenoptera: Braconidae) and its host Myzus persicae (Sulzer) (Homoptera: Aphididae) with mathematical proof of the relationship between female fecundity and the net reproductive rate. Environ. Entomol. 2006, 35, 10-21. [CrossRef]

61. Chi, H. CONSUME-MSChart: A Computer Program for Consumption Rate Analysis Based on the Age Stage, Two-Sex Life Table; National Chung Hsing University: Taichung, Taiwan. Available online: http://140.120.197.173/Ecology/prod02.htm (accessed on 26 July 2019).

62. Efron, B.; Tibshirani, R.J. An Introduction to the Bootstrap; Chapman \& Hall Inc.: New York, NY, USA, 1993. 
63. Zhang, R.; Ji, D.; Zhang, Q.; Jin, L. Evaluation of eleven plant species as potential banker plants to support predatory Orius sauteri in tea plant systems. Insects 2021, 12, 162. [CrossRef]

64. Wang, S.; Chi, H.; Liu, T. Demography and parasitic effectiveness of Aphelinus asychis reared from Sitobion avenae as a biological control agent of Myzus persicae reared on chili pepper and cabbage. Biol. Control 2016, 92, 111-119. [CrossRef]

65. Wang, Y.S.; Yao, F.L.; Soares, M.A.; Basiri, S.E.; Amiens-Desneux, E.; Campos, M.R.; Lavoir, A.V.; Desneux, N. Effects of four non-crop plants on life history traits of the lady beetle Harmonia axyridis. Entomol. Gen. 2020, 40, 243-252. [CrossRef]

66. Nagasaka, K.; Sagisaka, A.; Moriya, S.; Mitsunaga, T. Host-range study about four aphid parasitoid species among 16 aphid species for constructing bankercplant systems. Appl. Entomol. Zool. 2020, 55, 249-257. [CrossRef]

67. Yu, J.Z.; Chen, B.H.; Güncan, A.; Atlıhan, R.; Gökçe, A.; Smith, C.L.; Gümüs, E.; Chi, H. Demography and mass-rearing Harmonia dimidiata (Coleoptera: Coccinellidae) using Aphis gossypii (Hemiptera: Aphididae) and eggs of Bactrocera dorsalis (Diptera: Tephritidae). J. Econ. Entomol. 2018, 111, 595-602. [CrossRef]

68. McCalla, K.A.; Keçeci, M.; Milosavljević, I.; Ratkowsky, D.A.; Hoddle, M.S. The Influence of Temperature Variation on Life History Parameters and Thermal Performance Curves of Tamarixia radiata (Hymenoptera: Eulophidae), a Parasitoid of the Asian Citrus Psyllid (Hemiptera: Liviidae). J. Econ. Entomol. 2019, 112, 1560-1574. [CrossRef] [PubMed]

69. Pizzol, J.; Pintureau, B.; Khoualdia, O.; Desneux, N. Temperature-dependent differences in biological traits between two strains of Trichogramma cacoeciae (Hymenoptera: Trichogrammatidae). J. Pest Sci. 2010, 83, 447-452. [CrossRef]

70. Tuan, S.J.; Lee, C.C.; Chi, H. Population and damage projection of Spodoptera litura (F.) on peanuts (Arachis hypogaea L.) under different conditions using the age-stage, two-sex life table. Pest Manag. Sci. 2014, 70, 805-813. [CrossRef] [PubMed]

71. Chen, X.; Xiao, D.; Du, X.Y.; Zhang, F.; Zang, L.; Wang, S. Impact of polymorphism and abiotic conditions on prey consumption by Harmonia axyridis. Entomol. Gen. 2019, 39, 251-258. [CrossRef]

72. Wang, S.S.; Chen, X.; Li, Y.; Pan, B.Y.; Wang, S.G.; Dai, H.J.; Wang, S.; Tang, B. Effects of changing temperature on the physiological and biochemical properties of Harmonia axyridis larvae. Entomol. Gen. 2020, 40, 229-241. [CrossRef]

73. Yao, F.L.; Ding, X.L.; Mei, W.J.; Zheng, Y.; Desneux, N.; He, Y.X.; Weng, Q.Y. Impact of heat stress on the development of egg and adult coccinellid Serangium japonicum: Evidence for cross-stage and cross-generation effects. Entomol. Gen. 2020, 40, 365-376. [CrossRef]

74. Mu, J.Y.; Wang, N.C.; Fan, Y.G. Studies on the life histories and bionomics of four species of green lacewings. Acta Phytophylacica Sin. 1980, 15, 123-127.

75. Zhao, J.Z. Studies on the bionomics of Chrysopa septempunctata Wesmoer. Acta Phytophylacica Sin. 1988, 15, $123-127$.

76. Milosavljević, I.; McCalla, K.A.; Morgan, D.J.W.; Hoddle, M.S. The effects of constant and fluctuating temperatures on development of Diaphorina citri (Hemiptera: Liviidae), the Asian citrus psyllid. J. Econ. Entomol. 2020, 113, 633-645. [CrossRef]

77. Castellanos, N.L.; Bueno, A.F.; Haddi, K.; Silveira, E.C.; Rodrigues, H.S.; Hirose, E.; Smagghe, G.; Oliveira, E.E. The fitness and economic benefits of rearing the parasitoid Telenomus podisi under fluctuating temperature regime. Neotrop. Entomol. 2019, 48, 934-948. [CrossRef]

78. Braz, É.C.; Bueno, A.D.; Colombo, F.C.; de Queiroz, A.P. Temperature impact on Telenomus podisi emergence in field releases of unprotected and encapsulated parasitoid pupae. Neotrop. Entomol. 2021, 50, 462-469. [CrossRef] [PubMed]

79. El-Serafi, H.A.K.; Abdel-Salam, A.H.; Abdel-Baky, N.F. Effect of four aphid species on certain biological characteristics and life table parameters of Chrysoperla carnea Stephen and Chrysopa septempunctata Wesmael (Neuroptera: Chrysopidae) under laboratory conditions. Pak. J. Biol. Sci. 2000, 3, 239-245.

80. Khanamani, M.; Fathipour, Y.; Talebi, A.A.; Mehrabadi, M. Quantitative analysis of long-term mass rearing of Neoseiulus californicus (Acari: Phytoseiidae) on almond pollen. J. Econ. Entomol. 2017, 110, 1442-1450. [CrossRef]

81. Henry, L.M.; May, N.; Acheampong, S.; Gillespie, D.R.; Roitberg, B.D. Host-adapted parasitoids in biological control: Does source matter? Ecol. Appl. 2010, 20, 242-250. [CrossRef] [PubMed]

82. Julian, R.G.; Jian, J.D.; Kaitlin, R.; Judith, H.G.; Ellen, A.A. Laboratory adaptation of a native North American parasitoid to an exotic wood-boring beetle: Implications for biological control of invasive pests. J. Pest Sci. 2019, 92, 1179-1186.

83. Pan, M.Z.; Liu, T.X.; Nansen, C. Avoidance of parasitized host by female wasps of Aphidius gifuensis (Hymenoptera: Braconidae). The role of natal rearing effects and host availability? Insect Sci. 2018, 25, 1035-1044. [CrossRef] [PubMed]

84. Ghaemmaghami, E.; Fathipour, Y.; Bagheri, A.; Talebi, A.A.; Reddy, G.V.P. Quality control of the parasitoid wasp Trichogramma brassicae (Hymenoptera: Trichogrammatidae) over 45 generations of rearing on Sitotroga Cerealella. Insect Sci. 2021, 28, 180-190. [CrossRef] [PubMed]

85. Rana, J.S.; Dixon, A.F.G.; Jarosik, V. Costs and benefits of prey specialization in a generalist insect predator. J. Anim. Ecol. 2002, 71, 15-22. [CrossRef]

86. Zhao, Y.; Zhao, C.L.; Yang, X.; Chi, H.; Dai, P.; Desneux, N.; Benelli, G.; Zang, L.S. Yacon as an alternative host plant for Encarsia formosa mass-rearing: Validating a multinomial theorem for bootstrap technique in life table research. Pest Manag. Sci. 2021, 77, 2324-2336. [CrossRef]

87. Lumbierres, B.; Madeira, F.; Roca, M.; Pons, X. Effects of temperature and diet on the development and reproduction of the ladybird Oenopia Conglobate. Entomol. Gen. 2021, 41, 197-208. [CrossRef] 
88. Ghaderi, S.; Minaei, K.; Kavousi, A.; Akrami, M.A.; Aleosfoor, M.; Ghadamyari, M. Demographic analysis of the effect of Fenpyroximate on Phytoseiulus persimilis Athias-Henriot (Acari: Phytoseiidae). Entomol. Gen. 2013, 34, 225-233. [CrossRef]

89. Desneux, N.; Decourtye, A.; Delpuech, J.M. The sub-lethal effects of pesticides on beneficial arthropods. Annu. Rev. Entomol. 2007, 52, 81-106. [CrossRef] [PubMed] 